\title{
初中道德与法治课中加强道德实践的应用探究
}

\author{
李红玲 \\ 吉林省珲春市第三中学 \\ DOI:10.32629/er.v2i3.1730
}

[摘 要] 道德实践活动是促进德育影响转化为学生品德的基础。学生在道德形成过程中要完成由知到信,从信到行的两次转 变,道德实践环节必不可少。新教材道德与法治课注重道德实践, 倡导从学生实际出发,引导学生自主参与活动。改变灌输式课 堂旧现状,加强道德与法治课中的道德实践显得尤为迫切。

[关键词] 道德与法治课; 道德实践; 品德教育

\section{1 初中生在道德与法治课程中加入道德实践内容的重} 要意义

1.1 对现阶段教学模式现状的改变

我国初中阶段的教学目标在道德与法治课程中的体现 就是培养学生的思想道德的品质培养。新课改中的课程目标 当中指出教师要: “注重与学生生活和社会实践之间的联系, 扩展和提升他们的经验。”人教版初中道德与法治是紧密结 合社会时代发展和更新的, 课程的本质就是体现学生的 “社 会责任感和实践能力”。课程通过道德实践的介入将课本内 容中的教学案例和基本内容进行深入探讨和分析, 能将枯燥 的知识具体形象的展示, 进而促进学生对知识的掌握和理解, 带动整个课堂的学习氛围, 从而改变我国传统教学内容, 实 现现阶段新课标的教学目标的完成。

1.2 解决思想品德教育中学生的知行脱节, 由知到行必 须经过道德实践来转化

在二十几年的教学实践中, 我发现某些中学生知行严重 脱节, 他们有道德认知能力, 却缺乏良好的行为习惯。在应试 教育的指挥棒下, 很多教师只是把学生当作接受道德的 “容 器”, 教学脱离实践, 简单灌输抽象理论的做法, 使学生成为 认知上的巨人和行为上的矮子。道德 “知”、“行” 是德育过 程中的两个关键阶段。学生在道德形成过程中要完成由知到 信, 从信到行的两次转变, 道德实践环节必不可少。通过道德 实践触及学生的 “灵魂”, 才能转化为实际行动。

1.3 落实课程内容在学生的生活行为中

教学目标明确之后, 教师可以将学生在生活中遇到的问 题和成长中的烦恼, 教师可以按照我国的法律、道德、教育、 心理等方面的知识进行综合组织, 设定全新的教学课程计划 和内容, 给学生提供一个合理可行的解决或改善的方法, 学 生将学习知识和自己的实际情况相结合, 能在过程中不断提 升学生个人的独立思考能力和判断力。初中阶段道德与法治 的教师通常在讲授教学内容时只是流于课程内容的表面, 通 常不会进行教学内容的深度拓展, 这样就会造成学生较为被 动的进行学习, 影响教学内容的正常进行。这种教学模式之 下学生也不知道如何将课堂知识进行合理利用。因此道德实 践的应用显得尤为重要。

\section{2 初中道德与法治课中加强道德实践的措施}

2.1 课堂教学多创设情境体验, 做到思想认识和行动能 力的和谐统一

苏霍姆林斯基说得好: “道德, 只有当它被学生自己去追 求, 获得亲自体验的时候, 才能真正成为学生的财富。”教师 可以通过精心准备的情境模拟, 真实地再现学生熟悉的某些 生活场景, 创设真实的实践体验活动, 触发学生对思想道德 的切身体验, 组织和引导学生全身心地参与实践, 用心体验, 用心感受, 不断把道德要求内化为自身的品德。道德与法治 七年级下册《我们的情感世界》中先让学生观看升国旗仪式, 提问: 会让我们产生什么样的情感? 还设置了情境体验: 当 我们看到有人遭受欺辱, 你会产生什么样的情感? 如果能挺 身而出, 出手相助, 我们会体验到正义感。通过开展体验式德 育教育实践, 力求使学生形成 “会自主、能参与、重体验、 有感悟” 的认知过程, 做到思想认识和行动能力的和谐统一。 这样才能真正提高德育的效能, 有效提升德育的实效性。

2.2 课堂教学内容中真实案例的引入

在初中道德与法治的课程当中将真实案例带入到课堂 学习内容中, 可以成为教师在进行课堂内容教授的可行、并 适合广泛推广的方法。道德与法治课程中的知识点通常都比 较抽象, 但是一般情况下都会附带案例助学。教师在讲解课 文的时候可以将具体案例引入到课堂当中, 并让学生提供过 案例进行深入分析和思考。对于教学中出现的违法人物的行 为, 教学应该及时对学生进行正确引导, 教学生认识到今后 自己不能成为这种违法份子, 树立学生正确的行为观念, 加 强学生自身的社会责任感, 从而更好的完成教学目标。

2.3 通过参与式道德实践模式来丰富学生的道德生活经 验

德育生活化是提高德育实效性的一剂良方。德育应回归 生活, 从政治说教里走出来, 由 “远、大、空” 转变为 “近、 小、实”, 由抽象转变为具体。在生活的体验中培养良好的 道德素养。关注和引导学生的现实生活, 让学生在生活中体 验, 在体验中内化, 在内化中践行。如: 七年级上册《走进老 师》一课, 布置体验活动: 让学生对老师一天的工作进行记 录考察采访, 通过真切的感受去了解老师的辛苦与付出。课 
堂上进行师生角色互换, 让学生扮演老师去解决课堂纪律问 题, 平常故意捣乱的学生也体会到老师的无奈和气愤。感同 身受的参与往往胜过苦口婆心的说教。让中学生在道德生活 的实践中, 培养他们的道德素养, 通过涵养品格, 形成正确的 价值认同。

\section{4 情境体验给道德实践提供先决条件}

教师在进行道德与法治课程进行前期应该准备好教案 和情境设定。让学生在生活中遇到的事件和课堂学习内容紧 密结合起来。生活中的场景在课堂上再现, 让学生参与其中, 让学生能结合自己的实际情况产生共并触动自己的切实感 受, 从而将道德与法课程中的核心思想内化为自身所具备的 品质。学生通过课程内容的参与体验, 能够将课程内容更好 的吸收。道德语法的教材内容相对于其他课程来讲贴近社会 和生活。将这一课程的特点进行情境设计和研究, 让学生进 行情境设定的参与首先与课堂内容的主题相吻合, 比方说在 人教版道德与法中《做情感的主人》可以先让学生观看新闻 播报中的 “校园欺凌”。首先提问学生在对同学产生不满时 应该怎么做? 通过法律知识的介入和传授冷静的小方法, 让 学生养成遇事理智冷静的思想行为习惯, 从而维护好与同学 之间的关系, 从根本上和意识上让学生避免出现这种情况, 通过这种适度的情节带入能让学生更好的掌握教学内容, 并 有助于形成一个健全并懂得自控调解的优秀思想道德品质。

2.5 把握时代的脉搏, 理论联系实际, 引导学生进行符合 道德的行为训练与道德实践

政治课是一门时代性和实践性都很强的学科。脱离时代 的政治课除了一味的说教之外就是缺乏生气的一潭死水。因 此, 在教学中必须强调结合实际, 对社会中的热点问题不回 避, 不教条, 合情合理的进行利弊分析, 再给出具体的行动方 案, 训练如何道德实践。如: 老人摔倒后扶还是不扶是近几 年的热点话题, 让学生先讨论后发言, 摸清学生的思想动态。 假设情境: 如果摔倒的老人就是你的亲人, 你希望周围的人 怎么去做? 最后落实到实际行动中: 我们应该怎样做？针对 社会现状, 具体指导学生: 生活中确实有讹诈现象, 可以在拍 照或别人作证情况下扶老人起来, 即使不扶最起码也要打 120 急救电话。引导价值认同: 决不能漠视不管。运用课本 知识敬畏生命, 关爱他人, 社会责任感等知识让学生认识扶
的意义。再结合实际给予行为指导。并对可能遇到的困难分 析指导, 以提高实践的效果; 从而让道德实践具体可行。在 学生课后的具体实践中注意检查督促, 给予恰当的评价, 表 扬先进, 激励后进。

2.6 通过现代社会的热门事件来具体实施道德实践的活 动

道德与法治课程是政治很强的一门学科, 与社会时代之 间的关系非常紧密。教师在进行教学时应该注意结合现今社 会事件, 将道德实践的重要作用体现出来。并通过将社会事 件中的具体利害关系分析出来, 对学生进行行为指导, 从而 进行道德实践。如: 现阶段国家推行的车让人行为。同学之 间通过讨论分析出为驾驶员和行人各自应该注意的问题。同 学之间进行分角色假设, 具体指导学生在自己身为驾驶员的 情况下要注意在斑马线放慢速度, 遇到行人进行礼让。在自 己作为行人的时候遇到礼让行为表示感谢并快速通过。对于 双方来讲都不能出现闯红灯的行为, 行人在通过时不能故意 散漫, 似乎在故意挑畔驾驶员, 双方应该互相尊重理解, 避免 产生不必要的交通事故。这样既能教会学生在生活中遇到类 似行为的处理方法, 也能让学生将整个课程的教学内容更好 的理解, 提高自己的学习兴趣和效率, 使个人更好的发展。

\section{3 结语}

总之, 道德实践活动是促进德育影响转化为学生品德的 基础。让学生在亲身参与的各项活动中, 不断培养道德情感, 提高道德判断能力和行为选择能力, 从而把社会道德规范 “内化” 为个体的道德意识, “外化” 为个体的道德行为, 实现知与行的统一。但道德实践的深入持久的落实需要教师 精心的课堂设计和丰富的课外活动的支撑。双管齐下才能不 断加强道德实践的实效性。

\section{[参考文献]}

[1]赵玉婷.初中道德与法治课中加强道德实践的应用 探究[J].考试周刊,2018(4):46.

[2]张美贞,旷新华.互动式教学模式在初中道德与法治 课教学中的应用与实践 [J]. 中学课程辅导: 教师通 讯,2016(18):78.

[3]李大更.互动式教学模式在初中道德与法治课教学中 的应用与实践[J].教育科学:全文版,2016(12):71. 